\title{
Exchange Rate Volatility and Trade: An Empirical Investigation from the Egyptian Economy
}

\author{
Osama M. Badr ${ }^{1} \&$ Ahmed F. El-khadrawi ${ }^{2}$ \\ ${ }^{1}$ Faculty of Commerce, Tanta University, Egypt \\ ${ }^{2}$ Faculty of Commerce, Damietta University, Egypt, Faculty of Islamic Economic and Finance, Umm Al-Qura University, \\ Saudi Arabia
}

Correspondence: Osama M. Badr, Faculty of Commerce, Tanta University, Egypt.

Received: May 27, 2018

doi:10.11114/aef.v5i4.3318
Available online: June 26, 2018

URL: https://doi.org/10.11114/aef.v5i4.3318

\begin{abstract}
The main aim of this paper is to assess empirically the impact of exchange rate volatility (ERV) on the export and import functions in reference to Egypt's major trading partners over the period of 1980-2016. Estimates of a cointegration relationship are obtained using the ARDL model. The conditional variance of the GARCH $(1,1)$ model is taken as a proxy for exchange rate fluctuation. The observed outcomes reveal a significant negative coefficient of volatility on export and a non-significant positive coefficient on import. Indeed, this finding supports the traditional view that higher volatility will decrease export. To avoid the negative consequences of ERV, policymakers should shift from the concept of specialization based on the comparative advantage to competitive advantage and focus on the diversification of Egyptian exports while avoiding risks associated with market concentration by exploring potential opportunities that would increase trade openness by expanding Egypt's trade with other countries, especially with low and middle-income and emerging countries.
\end{abstract}

Keywords: exchange rate volatility, trade, Egypt, GARCH $(1,1)$ model, ARDL

JEL Classification: C53, F31, F44, C23, G15, O24, F1.

\section{Introduction}

After the Bretton-Woods agreement collapsed, major currencies have been floated instead of having a fixed rate against the US dollar, and since then, the exchange rates have been highly volatile. Thus, exchange rates' uncertainty has increased and affects both producers and consumers, which means that the rate has had a negative impact on international trade (Hitiris, 1988). Furthermore, according to Grauwe (1998), there has been a more than 50\% reduction in the growth rate of international trade since the floating regime was applied. However, this point of view is inconclusive, as many researchers argue that the impact of exchange rate variability may vary across countries as well as across sectors. This variation might occur for a number of reasons, such as the level of competition, openness to international trade, and the nature of contracts.

The theoretical analysis of the relationship between the increasing volatility of the exchange rate and international trade began with the study conducted by Hoope and Kohlhagan (1978), which was followed by many other studies, both theoretical and empirical. Most of these studies show that exchange rate uncertainty may have either a positive or negative effect on trade flows, referring to inconclusive results.

In this paper, we aim to empirically investigate the impact of ERV on both exports and imports by focusing on the Egyptian case over the period of 1980-2016. Hereby, we use a systematic approach. In the first step of measuring ERV, we apply the Generalized Autoregressive Conditional Heteroscedastic (GARCH) model of order $(1,1)$. The second step uses the Augmented Dickey-Fuller (ADF) to test the integration order of the variables used in the study. For the third step, to test the long-run relationship, the study adopted the Auto Regressive Distributed Lag (ARDL) bound testing procedure. At the same time, we will take into consideration the structure breaks to determine the effect of these on Egyptian exports.

This paper is divided into five sections. The first section encompasses the literature review of those theoretical and empirical findings concerned with the impact of ERV on export and trade. The second section focuses on the Egyptian 
case and provides a brief description of the pattern of evolution of exchange rate regimes. The third section presents the empirical model and the estimation technique. The fourth section discusses the empirical results, while the last section presents a brief summary and our conclusions.

\section{Literature Review}

Marston (1987) noted that "There are two types of exchange rate variability, volatility, and misalignment. Volatility is the day-to-day, month-to-month variability of exchange rates. Misalignment, in contrast, is the persistent departure of an exchange rate from its long-run competitive level." However, it is expected that both types of variation have important impacts on international trade flows.

In this context, a considerable number of studies have investigated the impact of exchange rate volatility on international trade. However, both theoretical and empirical studies have found that the ERV has an inconclusive impact on trade flows. From the theoretical point of view, these impacts could have either positive, negative or ambiguous effects on trade, depending on the temporal horizon of commercial transactions, the decisions made about risk preferences, and the availability of capital markets. For instance, several studies, including Ethier, (1973), Hooper and Kohlhagen (1978), De Grauwe, (1988), Brada and Mendez (1988), Viaene and de Vries (1992), De Grauwe (1994), Secru and Uppal (2000), Doyle (2001), and Baak (2004), found a significant negative impact of ERV on the volume of international trade. De Grauwe (1988) argued that risks associated with the uncertainty of the exchange rate have two effects that work in two different directions, namely the substitution effect and the income effect. According to Cote (1994), the negative effects on foreign trade take place either directly as a result of the adjustment costs or indirectly through the reallocation of resources and government decisions. However, by developing a theoretical model, Bacchetta and Wincoop (2000), showed that there is no relationship between the variables mentioned and international trade. Conversely, other studies, including Frank (1991), Sercu and Vanhulle (1992), have found that the impact of ERV could be positive or ambiguous. Viaene and deVries (1992) showed that the nature of this impact depends on both aggregate exposures to currency risk and risk aversion.

On the empirical side, the findings were also inconclusive. Hayakawa and Kimura (2009) argued that this variation in the effect of ERV on export volume may be due to different reasons, such as the choice of the sample used in the regressions, the model's specification, the region or country under consideration, and the variables used as proxies for the ERV.

Nonetheless, most empirical studies tend to find a negative impact of ERV on international trade. For instance, Chowdhury (1993) examined, for the period of 1973-1990, the impact of ERV on the trade flows of G-7 countries. The findings provide evidence of a significant negative impact on export volume for each country in the G-7. According to Chowdhury (1993), an increasing ERV causes additional costs and risk aversion for both exporters and importers. In addition, Brada and Mendez (1988) stated that unexpected ERV would induce governments to erect trade barriers to mitigate the negative consequences, thereby reducing the flows and volume of international trade.

Ozturk and Kalyoncu (2009) examined the relationship between ERV and trade flows for six countries for the period of 1980-2005. Their major results confirmed that the ERV have disparate impacts on the countries under study. They found that increased volatility in exchange rate reduced real exports in South Korea, Poland, South Africa and Pakistan, while it had a positive impact on those in Hungary and Turkey.

Similarly, Chit et al. (2010) used cointegration and gravity models to explore the impact of bilateral exchange rate volatility on exports across five emerging East Asian countries as well as towards thirteen industrialized countries. Their finding provides evidence that ERV has a significant negative impact on East Asian countries' real exports. The study also confirmed that both absolute and relative volatility play an important role in explaining bilateral trade between East Asian countries. Another similar study is that by Mohamad and Jusoff (2008), which studied the impact of ERV on the export performances of four Southeast Asian economies (Indonesia, Malaysia, Singapore and Thailand). They found that ERV has a negative and significant impact on export performances. They particularly suggested that an undervaluation of the real exchange rate can be used to promote exports, while an overvaluation will tend to reduce them.

Furthermore, Arize et al. $(2000 ; 2003$; 2008) investigated the impact of ERV on export demand in the context of developing countries. The results provided evidence that there is a significant negative relationship between increasing volatility in the exchange rate and export flows in both the short and long run in these countries. Using cointegration and ECM techniques, Baak (2004) detected the impact of ERV on the bilateral exports of 14 Asia-Pacific countries (APEC) using annual data over the period of 1980-2002. The results of the gravity model indicated a significant negative impact of ERV on export volume. Baak et al. (2007) attempted to reveal the impact of ERV on the exports of four East Asian countries towards the United States and Japan over the period of 1981-2004. The estimation results indicated a significant negative impact of ERV on exports in both the short and long run, except for Hong Kong's 
exports to Japan. Similarly, Bustaman and Jayanthakumaran (2007) investigated the short and long-run impacts of ERV on Indonesia's exports of priority goods to the US using monthly data covering the period of 1997-2005. The results obtained from the ECM show both positive and negative coefficients among the range of goods. However, the coefficients were negative for the majority of commodities in the long run. They confirmed that the net impact of ERV on exports depends on the degree of exporters' risk aversion. Similarly, Baek (2013) investigated the effects of ERV as well as another set of variables on the bilateral trade flows between South Korea and Japan. The results of their autoregressive distributed lag model (ARDL) indicated a negative relationship between the bilateral exchange rate and Korea's trade in the short run with less response in the long run. For the ERV, the results showed only a limited impact on bilateral trade in both the short and long runs.

Bahmani-Oskooee and Hegerty (2008) applied a cointegration analysis to examine the impact of ERV on bilateral trade between US and Japan. They used disaggregate data for 117 export and import industries from 1973 to 2006. They found that, in the short run, some industries were affected by ERV, although the results were often ambiguous. In the long run, only a relatively limited number of industries were affected by increased volatility. Similar results were also found in the study by Bahmani-Oskooee, Harvey and Hegerty (2014), which investigated the impact of ERV in US-Spain bilateral trade for 219 export and import industries over the period of 1962-2009. The results provided evidence that ERV has a significant effect on a limited number of industries. For 74 US export industries, the impact of ERV was positive for 11, negative for 24 and had no effect on the rest. Concerning imports, the results were similar as only 14 of 37 were affected ( 3 positively and 11 negatively).

More recently, Demirhan and Demirhan (2015) applied the multivariate cointegration method and the ECM model to analyze the relationship between ERV and real export volume in Turkey over the period of 2001-2010. The finding suggested that increasing ERV has a significant negative impact on exports, both in the short and long runs. Asteriou et al. (2016) examined the relationship between ERV and international trade volume for four countries (Mexico, Indonesia, Nigeria and Turkey) in both the short and long runs. In the long run, the results indicated no linkage between ERV and trade, except for Turkey. However, there is some evidence of a short-run relationship, whereby there was a significant causal relationship between ERV and exports for Mexico and Indonesia. For Nigeria, the causality was unidirectional from exports to ERV and there was no relationship detected in the case of Turkey.

In the literature on Egypt, Achy and Sekkat (2003) analyzed the impact of ERV on the export performance of selected five MENA countries, namely, Algeria, Egypt, Morocco, Tunisia and Turkey, by constructing panel data for 11 sectors over the period of 1970-1997. They found a negative effect of ERV for all exports except for the food sector. In the same context, Rey (2006) examined the impact of both the nominal and real effective ERV on the export demand of six countries from the MENA area towards fifteen EU member countries using quarterly data over the period of 1970-2002. The results showed a significant inverse relationship between ERV and real exports in Algeria, Egypt, Tunisia and Turkey, and a positive relationship for Israel and Morocco. Bouoiyour and Selmi (2013) combined a wavelet analysis with an optimal model chosen among various GARCH extensions in order to assess the effect of ERV on export performance. The results confirmed that volatility is more intense than at the high frequency, and conversely when subtracting the energy share from the total of exports. Bahmani et al. (2015) examined the effects of ERV on Egypt's trade with the EU using quarterly data for 59 industries' export and import flows. The findings were inconclusive, as few trade flows responded to increased risk in the short run. However, in the long run, a large proportion responded negatively.

The literature review shows that the effect of exchange rate volatility on trade was negative in many studies and inconclusive on other studies. This was the motivation to discuss the Egyptian case and to determine the effect of ERV on both exports and imports flows.

\section{A Brief Reading of the Exchange Rate Regime and Trade Policies in Egypt}

We can distinguish between three major stages in the historical evolution of the exchange rate regime in Egypt. From the 1960s till the 1990s, Egypt adopted a fixed but adjustable peg to the USD. During this period, the government began to reduce exchange rate restrictions, and tax concessions were granted in 1971 as a guarantee to foreign investors against the risk of property confiscation. At the beginning of 1991, Egypt began to implement economic reform and a structural adjustment program and changed its exchange rate policy by unifying the exchange rate system and transforming it into a "managing floating" regime. As a result, the Egyptian pound was devalued by $100 \%$ (from 1.55 LE per USD in 1990 to 3.13 LE per USD in 1991), and then was maintained fixed at approximately 3.36 LE per USD until 2000. From the year 1997, the Egyptian economy was exposed to numerous internal and external shocks which negatively affected the foreign sector. These shocks included: (1) The East Asian financial crisis that took place in the middle of 1997, which had a significant negative impact on capital market investment and provoked capital outflows from Egypt. (2) The Luxor terrorist attack in November 1997, causing a decline in tourism receipts and a slowdown in the tourism sector for several years. (3) The oil price shock of 1998 and its negative implications on the current account 
balance.

In January 2001, the government announced the adoption of the "crawling peg" system Kamar (2004). After three significant devaluations of the exchange rate during the period of 2001-2002, the Egyptian pound lost 30\% of its value, moving from 3.47 LE per USD to 4.49 LE per USD on average in 2002. The CBE expected that these devaluations, together with some currency injections, would lead to a market stabilization until the exchange rate recovered. However, the aftermath of the events of 9/11 with the subsequent war in Afghanistan and the invasion of Iraq neutralized the actions taken by the CBE and had negative impacts on the Egyptian economy. On January 28, 2003, the CBE announced a free float of the Egyptian pound. As a result of the new regime, the Egyptian pound declined by $30 \%$ against the USD, reaching 5.85 per USD on average, at the end of 2003, and by declined $0.6 \%$, reaching 6.19 LE per USD, at the end of 2004. Accordingly, the government responded by intervening to maintain the exchange rate stability by suspending imports for three months, excluding priority goods, and by fixing the price of fifteen basic commodities. In the mid of 2005, the CBE announced its intention to adopt inflation targeting as a framework for its monetary policy. During the second half of 2005, the Egyptian pound appreciated by $0.7 \%$ against the USD, then fluctuated within a tight range until the end of 2010 .

The two consecutive revolutions in 25th of January, 2011, and 30th of June, 2013, caused political and social instability in Egypt. On the economic level, specifically in the foreign trade sector, costs were quite considerable. Exports of goods and services decreased by $3.6 \%$, with an escalating imports bill of up to $2.5 \%$ compared with the same period of the previous year, which raised the trade deficit from USD 1.1 billion (5\% of GDP) in 2010 to USD 1.4 billion (6\% of GDP) in 2011 and to USD 2 billion (7\% of GDP) in 2012. However, the impact on the Egyptian pound was not as expected, as the pound remained quite stable against the USD (only a depreciation from 5.93 LE per USD in 2011 to 6.05 LE per USD in 2012). This behavior could be explained by the downward pressure on the international reserve, which occurred dramatically, suggesting that the authorities had been intervening heavily to support the pound CBE, (2011; 2012; 2013).

On March 14, 2016, the central bank announced moving toward "a more flexible exchange rate regime" as a step toward easing the international reserve shortage and increasing export competitiveness. The reference rate for the pound was set at 8.85 per USD from 7.73 and, as a result, the pound depreciated substantially.

On November 3, 2016, the authorities took the dramatic step of allowing the pound to trade freely in an attempt to stop the bleeding of foreign reserves and to narrow the margin between the black and official exchange market. As a result, the exchange rate fell from 8.78 LE per USD to 18 LE per USD. Although these measures can support the competitiveness of exports, a weaker pound will exacerbate prices of imported commodities.

\section{Nominal Versus Real Exchange Rate}

At the empirical level, the critical question arises about which exchange rate volatility (nominal or real) should be used. The answer depends on the time horizon under consideration. In the short and medium term, where prices are rigid, fluctuations in nominal and real exchange rates may be virtually the same. However, in the long run, there will be a reduction in the real exchange rate if the nominal exchange rates change to compensate for inflation differentials.

In theoretical models, the choice depends on the uncertainty of both exporters and importers. According to Gotur (1985) "the real exchange rate is the more relevant measure because the effects of uncertainty on a firm's revenues and costs that arise from fluctuations in the nominal exchange rate are likely to be offset in large part by movements in costs and prices." In the same context, De Grauwe (1994) notes "It should be stressed that the exchange rate uncertainty discussed here has to do with real exchange uncertainty. That is, the uncertainty comes about because the exchange rate changes do not reflect price changes."

Finally, no consensus has emerged regarding a conclusive way to measure the risks associated with ERV. However, our paper will focus on real exchange rate volatility.

\section{Modeling}

Our objective is to analyze the impact of ERV on the Egyptian trade flow. The models employed in this study depend on the determinants proposed by international trade theory after extending the models by incorporating ERV. Accordingly, the long-run real export and real import functions can be expressed as follows:

$$
\begin{aligned}
R X_{t} & =\alpha_{0}+\alpha_{1} R E R_{t}+\alpha_{2} R I R_{t}+\alpha_{3} Y_{T P}+\alpha_{4} I N F_{t}+\alpha_{5} V_{t}+\varepsilon_{t} \\
R M_{t} & =\alpha_{0}+\alpha_{1} R E R_{t}+\alpha_{2} R I R_{t}+\alpha_{3} G D P_{t}+\alpha_{4} I N F_{t}+\alpha_{5} V_{t}+\varepsilon_{t}
\end{aligned}
$$

Where RX denotes real exports; RM is the real imports; RER is the real exchange rate which calculated as: RER $=\mathrm{ER}$ [ CPId / CPIf ] where: ER is the nominal exchange rate expressed as the number of foreign currency units per local currency unit, $\mathrm{CPI}_{\mathrm{d}}$ is the consumer price index in Egypt, $\mathrm{CPI}_{\mathrm{f}}$ is the consumer price index in the USA; RIR denotes the real interest rate; $\mathrm{Y}_{\mathrm{TP}}$ is the real economic activity of the major trading partners of Egypt, generally expressed as 
GDP; GDP is the gross domestic product of Egypt; V denotes exchange rate volatility. L denotes that all the variables are used in their logarithmic form, the index $t$ refers to years and $\varepsilon_{\mathrm{t}}$ is the usual error term.

Theoretically, depreciation (appreciation) in the real exchange rate (RER) will raise (decrease) the export (import) volume, while raising (lowering) the real interest rate (RIR) will discourage (encourage) investment and exports. The economic activity of major trading partners (Y) has a positive effect on export volume. Gross domestic product (GDP) is expected to increase import volume. An increase (decrease) in the inflation rate will decrease (increase) the export (import) volume. Finally, ERV (V) may have a positive, negative or insignificant impact on trade volume.

\subsection{ERV Measurement}

It is worth noting that various methods have been used to capture the ERV. These methods include residual of ARIMA models (Asseery and Peel 1991), absolute percentage change of the exchange rates (for example, Bailey et al (1987)), and variance and/or standard deviations of the exchange rate (for example, Kenen and Rodrik (1986); Lastrapes and Koray (1990); Chowdhury, (1993)). Finally, there is the Generalized Auto Regressive Conditional Heteroscedasticity (GARCH) model (for example, Kenneth and William (1993); Helmut (2003); Choudhry, (2005); (2008)).

In this paper, we will apply the conditional variance of the GARCH $(1,1)$ model to estimate the predicted ERV. The model is assumed to be an appropriate measure with currencies volatility Bhargava and Malhotra (2007). Additionally, it can simultaneously capture volatility clustering and unconditional return distribution with heavy tails.

The GARCH model of the exchange rate used in this study is as follows:

$$
\begin{aligned}
& E R=\beta_{0}+\beta_{1} E R_{t-1}+\varepsilon_{t} \quad \varepsilon_{t} \sim N\left(0, \sigma_{t}^{2}\right) \\
& \sigma_{t}^{2}=\gamma+\alpha \varepsilon_{t-1}^{2}+\beta \sigma_{t-1}^{2}+\mu_{t}
\end{aligned}
$$

Where:

$\begin{array}{lll}\text { Equation (3) } & = & \begin{array}{l}\text { is the conditional mean equation } \\ \text { Equation (4) }\end{array} \\ \varepsilon_{\mathrm{t}} & = & \begin{array}{l}\text { is the conditional variance equation } \\ \varepsilon_{\mathrm{t}-1}^{2}\end{array} \\ \sigma_{\mathrm{t}-1}^{2} & \text { the heteroskedastic error term with its conditional variance }\left(\sigma_{\mathrm{t}}^{2}\right)\end{array}$

In $\operatorname{GARCH}(1,1), \gamma, \quad \alpha$ and $\beta$ are non-negative, which ensures that conditional variance $\left(\sigma_{\mathrm{t}}^{2}\right)$ is positive $(\alpha \geq 0$ and $\beta \geq 0$ ). For an accurate model, the sum of $\alpha$ and $\beta$ should be near unity. However, if the sum of the parameters is less than one, the volatility shock reduces over time. If the sum is equal to one, the shock will have an effect for an uncertain period.

\section{Estimation Procedure}

To estimate the equations $(1,2)$, we use the bound test procedure, namely the autoregressive distributed lag (ARDL) developed by Pesaran et al. (2001). According to Pesaran "the ARDL is being employed for cointegration analysis since it can be applied irrespective of whether the regressors are I(0), I(1) or mutually cointegrated". Moreover, it is unnecessary for the order of integration of the underlying regressors to be ascertained prior to testing the existence of a level relationship between two variables $y_{t}$ and $x_{t}$. The ARDL procedure involves two stages; the first is the Wald test (the F-statistic version of the bound testing approaches). We test the null hypothesis of the non-cointegration relation between the variables $\left(\mathrm{H}_{0}: \omega_{1}+\omega_{2}+\omega_{3} \ldots\right.$ etc $\left.=0\right)$ by performing a joint significance test on the lagged level variables. Pesaran et al. (2001) tabulated two sets of critical values; these two sets cover a band between $\mathrm{I}(0)$ and $\mathrm{I}(1)$, which gives three possibilities. First, if the test statistic (F-statistic) falls below the lower critical bound, the null hypothesis cannot be rejected, which means that there is no cointegration between the variables. Second, if the F-statistic exceeds upper critical bound, the null hypothesis is rejected, indicating that there is a cointegration relation between the variables. The result will be inconclusive if the F-statistic falls within the band. The second step of the ARDL approach is to estimate the coefficients of the long-run cointegrating relationship and the corresponding ECM (Badr and El-khadrawi, 2015).

In the following we augmented the models (1 and 2) to capture the ARDL model: 


$$
\begin{gathered}
\Delta L R X_{t}=c_{0}+\sum_{i=1}^{n} \alpha_{i} \Delta L R X_{t-1}+\sum_{i=1}^{n} \beta_{i} \Delta L R E R_{t-1}+\sum_{i=1}^{n} \mu_{i} \Delta L R I R_{t-1}+\sum_{i=1}^{n} \eta_{i} \Delta L Y_{T P}{ }_{t-1} \\
+\sum_{i=1}^{n} \varphi_{i} \Delta L I n f_{t-1}+\sum_{i=1}^{n} \psi_{i} \Delta L V_{t-1}+\omega_{1} L R E R_{t-1}+\omega_{2} L R I R_{t-1}+\omega_{3} L Y_{T P_{t-1}}+\omega_{4} L V_{t-1}+u_{t} \\
\Delta L R M_{t}=c_{0}+\sum_{i=1}^{n} \alpha_{i} \Delta L R M_{t-1}+\sum_{i=1}^{n} \beta_{i} \Delta L R E R_{t-1}+\sum_{i=1}^{n} \mu_{i} \Delta L R I R_{t-1}+\sum_{i=1}^{n} \rho_{i} \Delta L G D P_{t-1} \\
+\sum_{i=1}^{n} \varphi_{i} \Delta L \operatorname{Lnf} f_{t-1}+\sum_{i=1}^{n} \psi_{i} \Delta L V_{t-1}+\omega_{1} L R E R_{t-1}+\omega_{2} L R I R_{t-1}+\omega_{3} L G D P_{t-1}+\omega_{4} L V_{t-1}+u_{t}
\end{gathered}
$$

The lagged error correction term $\left(\mathrm{e}_{t-1}\right)$ derived from the error correction model (ECM) is an important element in the dynamics of a cointegrated system as it allows for an adjustment back to the long-term equilibrium relationship. The larger the error correction coefficient, in absolute value, the faster is the return of the exports (imports) to its long-run equilibrium once shocked.

\section{Empirical Results}

\subsection{ERV Measurement}

The results of estimating the GARCH method are represented in equation (7) as follows:

$$
\begin{aligned}
\sigma_{t}^{2}= & 0.003694+0.626964 \varepsilon_{t-1}^{2}+0.088899 \sigma_{t-1}^{2} \\
& (0.04443) \quad(0.00254) \quad(0.04809)
\end{aligned}
$$

The findings indicate that exchange rate follows a GARCH $(1,1)$ model as the coefficients of the ARCH term $\left(\varepsilon_{\mathrm{t}-1}^{2}\right)$ as well as the GARCH term $\left(\sigma_{\mathrm{t}-1}^{2}\right)$ are statistically different from zero and significant at the $5 \%$ level, which implies accepting the existence of volatility clustering. The sum of coefficients is less than unity, which indicates that shocks are reducing over time.

\subsection{Order of Integration}

Before turning to the estimation results, it is important to make a preliminary test that assesses whether the variables used in equations (1 and 2) are I(0) or I(1) by employing the ADF test. The results of the unit root test in table (1) in the Annex imply that different orders of integration occur amongst the variables under consideration. Accordingly, the estimation of a model could be done by employing the ARDL bound testing approach.

\subsection{Cointegration Test}

Before running the ARDL regression, It's important to determine the optimum length of the lag(s). Table (2) in the Annex gives the results using the Akaike Information Criteria (AIC), Schwartz Bayesian Criteria (SBC) and Hannan-Quinn Criteria (HQC). Using the results of optimal value, we proceed to estimate equations $(5,6)$ in order to determine whether a long-run relationship exists. Table (3) in the Annex shows that the F-statistics lies within the two bounds' limits, indicating that the cointegration among the variables is inconclusive. Given these results, we removed the non-significant variable (or variables that had no long-run relationship) (i.e., RIR in exports equation and RIR, INF, and $\mathrm{V}$ in imports equation) one by one and carried out the same estimation at each time. Tables (4a and 4b) in the Annex show the ARDL estimation for both the exports and imports equations.

According to the results derived from Table (4a), all variables have signs, as expected from the theoretical propositions and, except for the real interest rate, are significant. The coefficients of ERV and INF have negative impacts on export. The estimates imply that a $1 \%$ additional increase in exchange rate volatility and inflation leads to a deterioration in export value by 0.22 and $0.13 \%$, respectively.

The results for the imports equation are shown in Table (4b). According to the findings, the coefficient of ERV has a positive sign, as predicted. However, it is insignificant at all levels of confidence. Consistent with predictions, the real exchange rate and gross domestic product have positive effects on the long run of import volume. The estimate shows imports elasticities of 0.11 and 0.07 with these two variables, respectively. Furthermore, the coefficients of interest rate and inflation rate have predicted signs, but are not significant, even at $10 \%$.

It also observed that for both exports and imports the error-correction term (ECT) is negative and statistically significant, confirming that there is a long-term relationship between real export (real import) and the variables under consideration. The adjustment force is 0.047 and 0.67 for exports and imports, respectively, implying that less than $1 \%$ of the disequilibrium in period $\mathrm{t}-1$ is revised in period t. For imports, the results imply a high speed of adjustment. 


\section{Conclusion and Recommendation}

This paper has analyzed the impact of exchange rate volatility on Egyptian trade with the respective groups, the European Union, the Arab world, the United States, and South Asia, as the most important partners. The ERV was estimated by applying the conditional variance of the GARCH $(1,1)$ model. The long-run relationship between the ERV and trade was estimated using the ARDL cointegration approach for the period of 1980-2016. For exports, the findings support the traditional economic view, namely that shock disturbance leads to high costs, which depress export volume. However, the net effect of risks associated with exchange rate uncertainty depends on the degree of exporters' risk aversion as well as the reallocation of resources and government decisions. In the case of imports, the ERV non-significantly encourages imports. The short-run analysis shows that for both exports and imports, the error correction terms had the expected negative signs and were significant. The speed of adjustments varied from low (for export) to high (for import).

On the whole, our results show that the adverse effects of exchange rate fluctuations can be avoided by shifting from the concept of specialization based on a comparative advantage to a competitive advantage as well as a diversification of Egyptian exports and avoiding the risks associated with market concentration by expanding and trading mainly with low and middle-income and emerging economies. This can be furthered by conducting bilateral trade in their currencies rather than using a vehicle currency. These results have important implications for Egypt, where trade is concentrated in only a few countries. Policymakers need to explore potential opportunities that would increase trade openness by expanding Egypt's trade with other countries.

\section{References}

Achy, L., \& Sekkat, K. (2003). The European Single Currency and MENA's Export to Europe, Review of Development Economies, 7(4), 563-582. https://doi.org/10.1111/1467-9361.00209

Akhtar, M. A., \& Hilton, R. S. (1984). Effects of Exchange Rate Uncertainty on German and U.S. Trade, Federal Reserve Bank of New York Quarterly Review, 9(1), 7-15.

Arize, A. C., Malindretos, J., \& Kasibhatla, K. M. (2003). Does Exchange-Rate Volatility Depress Export Flows: The Case of LDCs. International Advances in Economic Research, 9(1), 7-19. https://doi.org/10.1007/BF02295297

Arize, A. C., Osang, T., \& Slottje, D. J. (2000). Exchange rate volatility and foreign trade: evidence from thirteen LDCs, Journal of Business and Economic Statistics, 18, 10-17.

Arize, A. C., Osang, T., \& Slottje, D. J. (2008). Exchange-Rate Volatility in Latin America and Its Impact on Foreign Trade, International Review of Economics and Finance, 17(1), 33-44. https://doi.org/10.1016/j.iref.2006.01.004

Asseery, A. A., \& Peel, D. A. (1991). The Effects of Exchange Rate Volatility on Exports: Some New Estimates, Economics Letters, 37(2), 173-177. https://doi.org/10.1016/0165-1765(91)90127-7

Asteriou, D., Masatci, K., \& Pilbeam, K. (2016). Exchange rate volatility and international trade: International evidence from the MINT countries, Economic Modelling, 58, 133-140. https://doi.org/10.1016/j.econmod.2016.05.006

Baak, S. J., Al-Mahmood, M. A., \& Vixathep, S. (2007). Exchange Rate Volatility and Exports from East Asian Countries to Japan and the USA, Applied Economics, 39(8), 947-959. https://doi.org/10.1080/00036840500474231

Baak, S. J. (2004). Exchange Rate Volatility and Trade among the Asia Pacific Countries. IUJ Research Institute, Working Paper 2004-5. https://doi.org/10.2139/ssrn.3079180

Bacchetta, P., \& van Wincoop, E. (2000). Does Exchange rate Stability Increase Trade? The American Economic Review, 90, 1093-1109. https://doi.org/10.1257/aer.90.5.1093

Badr, O. M., \& El-khadrawi, A. F. (2015). Reserve holdings and macroeconomic variables: An empirical dynamic analysis in Egyptian economy. International Journal of Trade, Economics and Finance, 6(2), 90-95. https://doi.org/10.7763/IJTEF.2015.V6.449

Baek, J. (2013). Does the exchange rate matter to bilateral trade between Korea and Japan? Evidence from commodity trade data. Economic Modelling, 30, 856-862. https://doi.org/10.1016/j.econmod.2012.11.020

Bahmani, O. M., \& Hegerty, S. W. (2008). Exchange-Rate Risk and US-Japan Trade: Evidence From Industry Level Data, Journal of the Japanese and International Economies, 22, 518-534. https://doi.org/10.1016/j.jjie.2008.09.002

Bahmani, O. M., Hegerty, S. W., \& Hosny, A. (2015). Exchange-rate volatility and commodity trade between the E.U. and Egypt: evidence from 59 industries, Empirica, Springer, 42(1), 109-129. https://doi.org/10.1007/s10663-014-9250-6

Bailey, M. J., Tavlas, G. S., \& Ulan, M. (1987). The Impact of Exchange Rate Volatility on Export Growth: Some 
Theoretical Considerations and Empirical Results., Journal of Policy Modeling, 9(1), 225-243. https://doi.org/10.1016/0161-8938(87)90010-X

Bhargava, V., \& Malhotra, D. K. (2007). The relationship between futures trading activity and exchange rate volatility, revisited, Journal of Multinational Financial Management 17(2), 95-111. https://doi.org/10.1016/j.mulfin.2006.05.001

Bouoiyour, J., \& Selmi, R. (2013). Exchange volatility and export performance in Egypt: New insights from wavelet decomposition and optimal GARCH Model, MPRA Paper No. 49140.

Brada, J. C., \& Mendez, J. A. (1988). Exchange rate risk, exchange rate regime, and the volume of international trade. Kyklos, 41(2), 263-280. https://doi.org/10.1111/j.1467-6435.1988.tb02309.x

Bustaman, A., \& J ayanthakumaran, K. (2007). The impact of exchange rate volatility on Indonesia' s exports to the USA: an application of ARDL Bounds testing procedure. International Journal of Applied Business and Economic Research, 5(1), 1-21.

Central bank of Egypt (CBE). annual report, different issues, 2011, 2012, 2013.

Chit, M., Rizov, M., \& Willenbockel. (2010). Exchange rate volatility and exports: New empirical evidence from the emerging East Asian economies, The World Economy, 33(2), 239-263. https://doi.org/10.1111/j.1467-9701.2009.01230.x

Choudhry, T. (2005). Exchange Rate Volatility and the United States Exports: Evidence from Canada and Japan. Journal of Japanese and International Economies, 19(1), 51-71. https://doi.org/10.1016/j.jjie.2003.11.002

Choudhry, T. (2008). Exchange Rate Volatility and United Kingdom Trade: Evidence from Canada, Japan and New Zealand, Empirical Economics, 35(3), 607-619. https://doi.org/10.1007/s00181-008-0185-2

Chowdhury, A. (1993). Does Exchange Rate Volatility Depress Trade Flows? Evidence from Error-Correction Models, The Review of Economics and Statistics, 75(4), 700-706. https://doi.org/10.2307/2110025

Cote, A. (1994). Exchange Rate Volatility and Trade. Bank of Canada, Working Paper, 94-5.

De Grauwe, P. (1988). Exchange rate variability and the slowdown in growth of international trade, IMF Staff Papers, 35(1), 63-84. https://doi.org/10.2307/3867277

De Grauwe, P. (1994). The economics of monetary integration. New York, NY: Oxford University Press.

Demirhan, E., \& Demirhan, B. (2015). The Dynamic Effect of Exchange Rate Volatility on Turkish Exports: Parsimonious Error-Correction Model Approach, Panoeconomicus, 62(4), 429-451. https://doi.org/10.2298/PAN1504429D

Doyle, E. (2001). Exchange Rate Volatility and Irish-UK Trade, 1979-1992. Applied Economics, 33, 49-503. https://doi.org/10.1080/00036840122999

Ethier, W. (1973). International trade and the forward exchange market, American Economic Review, 63(3), 494-503.

Franke, G. (1991), Exchange rate volatility and international trading strategy, Journal of International Money and Finance, 10, 292-307. https://doi.org/10.1016/0261-5606(91)90041-H

Gotur, P. (1985). Effects of exchange rate volatility on Trade: Some further evidence, IMF staff papers, 32(3), 475-512.

Hayakawa, K., \& Kimura, F. (2009). The effect of exchange rate volatility on international trade in East Asia. Journal of the Japanese and International Economies, 23(4), 395-406. https://doi.org/10.1016/j.jjie.2009.07.001

Herwartz, H. (2003). On the (Nonlinear) Relationship between Exchange Rate Uncertainty and Trade: An Investigation of US Trade Figures in the Group of Seven, Review of World Economics, 139(4), 650-682. https://doi.org/10.1007/BF02653108

Hitiris, T. (1988). The pure theory of international trade under condition s of uncertainty, in Zis et al. (eds), International Economics, Longman, London.

Hooper, P., \& Kohlhagen, S. W. (1978). The Effect of Exchange Rate Uncertainty on the Prices and Volume of $\begin{array}{llllll}\text { International Trade. Journal of International Economics, } & \text { 8, } & \text { 483-511. }\end{array}$ https://doi.org/10.1016/0022-1996(87)90001-8

Kamar, B. (2004). De facto exchange rate policies in the MENA region: Toward deeper cooperation., Economic Research Forum for the Arab countries, Beirut, Lebanon.

Kenen, P., \& Rodrik, D. (1986). Measuring and Analyzing the Effects of Short-term Volatility in Real Exchange Rates, $68,311-315$ 
Kenneth, F. K., \& William, D. L. (1993). The Impact of Exchange Rate Volatility on International Trade: Reduced Form Estimates Using the GARCH-in Mean Model, Journal of International Money and Finance, 12(3), $298-318$. https://doi.org/10.1016/0261-5606(93)90016-5

Lastrapes, W. D., \& Koray, F. (1990). Exchange Rate Volatility and U.S. Multilateral Trade Flows, Journal of Macroeconomics, 12, 341-362. https://doi.org/10.1016/0164-0704(90)90001-Q

Marston, R. C. (1987). Exchange Rate Policy Reconsidered, NBER Working Paper No. 2310.

Mohamad, S., \& Jusoff, H. K. (2008). Exchange rates and export growth in Asian economies. Asian Social Science, $4(11), 30-36$.

Ozturk, I., \& Kalyoncu, H. (2009). Exchange Rate Volatility and Trade: An Empirical Investigation from Cross-country Comparison, African Development Review, 21(3), 499-513. https://doi.org/10.1111/j.1467-8268.2009.00220.x

Pesaran, S., Smith, R., \& Shine, Y. (2001). Bound testing approaches to the analysis of level relationship, Journal of Applied Econometrics, 16, 289-326. https://doi.org/10.1002/jae.616

Rey, S. (2006). Effective Exchange Rate Volatility and MENA Countries Exports to the EU, Journal of Economic Development, 31(2), 23-54.

Secru, P., \& Uppal, R. (2000). Exchange rate Volatility, Trade, Capital Flows under Alternative Exchange Rate Regimes. Cambridge University Press, Chapter 6.

Sercu, P., \& Vanhulle, C. (1992). Exchange rate volatility, international trade, and the value of exporting firm, Journal of Banking and Finance, 16(1), 152-182. https://doi.org/10.1016/0378-4266(92)90083-C

Viaene, J. M., \& de Vries, C. G. (1992). International trade and exchange rate volatility, European Economic Review, 36, 1311-1321. https://doi.org/10.1016/0014-2921(92)90035-U

\section{Annex}

Table 1. Unit Root Test: ADF test

\begin{tabular}{lcc}
\hline Variable & ADF test & $\begin{array}{c}\text { Order of } \\
\text { integration }\end{array}$ \\
\hline $\log (X)_{N T}$ & $4.28^{*}$ & $\mathrm{I}(1)$ \\
$\log (M)_{N T}$ & $-3.63)$ & $\mathrm{I}(1)$ \\
$\log (E R)_{N T}$ & $\left(-3.60^{*}\right.$ & \\
& $-3.07^{* *}$ & $\mathrm{I}(0)$ \\
$\log (\text { rir })_{N T}$ & $(-2.94)$ & $\mathrm{I}(0)$ \\
$\log (Y)_{N T}$ & $-4.39^{*}$ & $\mathrm{I}(1)$ \\
$\log (G D P)_{T}$ & $-3.62)$ & $\mathrm{I}(1)$ \\
$\log (V)_{T}$ & $(-3.63 *$ & $\mathrm{I}(1)$ \\
\hline
\end{tabular}

Notes: *, **, *** indicates that variable is significant at $1 \%, 5 \%$, and $10 \%$ respectively. $\mathrm{T}$, indicates that Trend is significant. NT, indicates that trend is not significant. The number in parentheses represents the critical value of the ADF statistics at the retained significant level.

Table 2. Choice Optimal Lag(s)

\begin{tabular}{lcccc}
\hline Variable & $\boldsymbol{A I C}$ & $\boldsymbol{S B C}$ & $\boldsymbol{H Q}$ & Optimal lag \\
\hline $\log (X)$ & $46.99851^{*}$ & $47.08921^{*}$ & $47.02903^{*}$ & 1 \\
$\log (M)$ & $47.53310^{*}$ & $47.62379^{*}$ & $47.56361^{*}$ & 1 \\
$\log (E R)$ & -2.567225 & $-2.431179^{*}$ & $-2.521450^{*}$ & 2 \\
$\log ($ rir $)$ & $5.880191^{*}$ & $5.970888^{*}$ & $5.910708^{*}$ & 1 \\
$\log (Y)$ & $-4.861971^{*}$ & $-4.771273^{*}$ & $-4.831454^{*}$ & 1 \\
$\log (G D P)$ & $6.575985^{*}$ & $6.802728^{*}$ & $6.652277^{*}$ & 4 \\
$\log (V)$ & $-5.937694^{*}$ & $-5.846997^{*}$ & $-5.907177^{*}$ & 1 \\
\hline
\end{tabular}


Note: * indicates lag order selected by the criterion. AIC, SBC, and HQ are the Akaike information criterion, Schwarz information criterion, and Hannan-Quinn information criterion, respectively.

Table 3. F-Statistics for Existence of Long-run Relationships

\begin{tabular}{lc|lc}
\hline \multicolumn{3}{c}{ Exports Model } & Imports Model \\
\hline F-Statistic & 3.251962 & F-Statistic & 2.928087 \\
\hline Critical Value at 5\% & 3.189 (Lower) & Critical Value at 10\% & 2.782 (Lower) \\
& 4.329 (Upper) & & 3.827 (Upper) \\
\hline
\end{tabular}

Note: The critical values taken from Pesaran \& Shin (2001), Unrestricted intercept and trend with five regressors.

Table 4a. Estimation of Long-run Coefficients Using the ARDL

\begin{tabular}{lcc}
\hline \multicolumn{3}{c}{ Dependent Variable: Export Volume } \\
\hline Variable & $(\mathbf{1})$ & $(2)$ \\
\hline \multirow{2}{*}{ C } & 0.504 & 0.612 \\
& $(1.788)^{* * *}$ & $(2.049)^{* * *}$ \\
ER & 0.258 & 0.202 \\
RIR & $(3.318)^{*}$ & $(2.994)^{*}$ \\
& -0.166 & --- \\
$Y$ & $(-0.599)$ & 0.441 \\
& 0.414 & $(1.957)^{* * *}$ \\
Inf & $(1.790)^{* * *}$ & -0.132 \\
& -0.165 & $(-2.421)^{* *}$ \\
V & $(-2.467)^{*}$ & -0.218 \\
\multirow{2}{*}{ Ect } & -0.218 & $(-2.421)^{* *}$ \\
& $(-3.252)^{*}$ & -0.047 \\
& -0.0576 & $(-2.420)^{* *}$ \\
\hline
\end{tabular}

Note: $* * *$ and $* * *$ denote significant at $1 \%, 5 \%$ and $10 \%$ respectively. The number in parentheses are t-ratios.

Table 4b. Estimation of Long-run Coefficients Using the ARDL

\begin{tabular}{lcc}
\hline \multicolumn{3}{c}{ Dependent Variable: Import Volume } \\
\hline Variable & $(\mathbf{1})$ & $(2)$ \\
\hline \multirow{2}{*}{ C } & 0.596 & 0.313 \\
\multirow{2}{*}{ ER } & $(1.946)^{* * *}$ & $(2.047)^{* *}$ \\
& -0.189 & -0.114 \\
RIR & $(-1.910)^{* * *}$ & $(-1.815)^{* * *}$ \\
& -0.135 & --- \\
GDP & $(-0.349)$ & 0.0752 \\
\multirow{2}{*}{ Inf } & 0.105 & $(2.561)^{* *}$ \\
& $(3.159)^{*}$ & --- \\
V & 0.112 & \\
& $(0.014)$ & --- \\
Ect & 0.419 & -0.657 \\
& $(0.440)$ & $(-3.202)^{*}$ \\
\hline
\end{tabular}

Note: $* * *$ and $* * *$ denote significant at $1 \%, 5 \%$ and $10 \%$ respectively. The number in parentheses are t-ratios.

\section{Copyrights}

Copyright for this article is retained by the author(s), with first publication rights granted to the journal.

This is an open-access article distributed under the terms and conditions of the Creative Commons Attribution license which permits unrestricted use, distribution, and reproduction in any medium, provided the original work is properly cited. 